\title{
Hazard index maps for woody material recruitment and transport in alpine catchments
}

\author{
B. Mazzorana ${ }^{1,2}$, A. Zischg ${ }^{3,4}$, A. Largiader ${ }^{3}$, and J. Hübl ${ }^{2}$ \\ ${ }^{1}$ Department of Hydraulic Engineering, Autonomous Province of Bolzano/Bozen South Tyrol, Bolzano, Italy \\ ${ }^{2}$ Institute of Mountain Risk Engineering, University of Natural Resources and Applied Life Sciences, Vienna, Austria \\ ${ }^{3}$ Abenis AG, Chur, Switzerland \\ ${ }^{4}$ Abenis Alpinexpert srl, Bolzano, Italy
}

Received: 4 August 2008 - Revised: 5 February 2009 - Accepted: 9 February 2009 - Published: 19 February 2009

\begin{abstract}
A robust and reliable risk assessment procedure for hydrologic hazards deserves particular attention to the role of transported woody material during flash floods or debris flows. At present, woody material transport phenomena are not systematically considered within the procedures for the elaboration of hazard maps. The consequence is a risk of losing prediction accuracy and of underestimating hazard impacts. Transported woody material frequently interferes with the sediment regulation capacity of open check dams and moreover, when obstruction phenomena at critical crosssections of the stream occur, inundations can be triggered. The paper presents a procedure for the determination of the relative propensity of mountain streams to the entrainment and delivery of recruited woody material on the basis of empirical indicators. The procedure provided the basis for the elaboration of a hazard index map for all torrent catchments of the Autonomous Province of Bolzano/Bozen. The plausibility of the results has been thoroughly checked by a backward oriented analysis on natural hazard events, documented since 1998 at the Department of Hydraulic Engineering of the aforementioned Alpine Province. The procedure provides hints for the consideration of the effects, induced by woody material transport, during the elaboration of hazard zone maps.
\end{abstract}

\section{Introduction}

In European mountain regions significant losses resulting from torrent processes occurred during the last decades (e.g., Oberndorfer et al., 2007; Autonome Provinz Bozen -

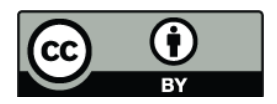

Correspondence to: B. Mazzorana (bruno.mazzorana@provinz.bz.it)
Südtirol, 2008), in spite of considerable efforts undertaken for the protection of endangered areas (Fuchs and McAlpin, 2005). A retrospective analysis on hazard maps highlighted a series of shortcomings with respect to torrential processes (Berger et al., 2007). In particular the effects of changing channel morphology and associated woody material transport phenomena were found to remarkably amplify process intensities (e.g., Diehl, 1997; Lyn et al., 2007). Considering the effects of woody material transport specifically, clear indications emerged from the analysis of the debris flow and flood events which recently occurred in several alpine regions (e.g., Rickli and Bucher, 2006). At critical channel geometry configurations such as bridge cross sections the transported woody material can be easily entrapped and subsequently partially or totally block the cross-sectional area for conveyance. In addition to increasing the loading conditions on the structural components of the bridges (e.g. piers and superstructure), overflowing becomes more frequent and therefore flood hazard impacts increase (Bezzola et al., 2003). Transported woody material frequently interferes directly with the sediment regulating capacity of open check dams (Lange et al., 2006). Clogging of the check dam openings during the early stages of debris flow events induces deposition when the intensity of the events is rather low. As a consequence, if the retention capacity is limited, a hazard mitigation performance can be expected which is far from optimum. In the procedures and regulations currently being used in hazard mapping, the assessment of such potential impacts is left to expert discretion. Decisions made in this way involve subjective assumptions concerning certain impact variables (e.g. woody material transport) and this affects the transparency, comparability and ultimately the quality of the hazard mitigation. In order to avoid such shortcomings in mitigation planning, we propose a procedure, which, based

Published by Copernicus Publications on behalf of the European Geosciences Union. 
on empirical indicators, determines the relative propensity of mountainous streams to the entrainment and delivery of woody material.

While the ecological and morphological role of woody debris in mountain streams have been extensively studied (Abbe et al., 1997; Hildebrand et al., 1997; Keim et al., 2002; Gurnell et al., 2002; Montgomery and Piegay, 2003; Comiti et al., 2006), hazard related topics of woody material transport have been less systematically investigated. Nevertheless, some literature exists concerning in-stream structures. For example, Diehl (1997) studied the damage potential of transported woody material and Shields et al. (2001) analyzed the relation between flow resistance and increased inundation frequency due to the presence of large woody material. New insights into the dynamics of wood transport in streams have been achieved through flume experiments (Braudrick et al., 1997; Braudrick and Grant, 2000, 2001; Curran et al., 2003; Degetto, 2000; Rickenmann, 1997; Haga et al., 2002). The interaction of woody debris transport with protection measures has been investigated with a special focus on check dams (Bezzola et al., 2004; Lange et al., 2006; Uchiogi et al., 1996) and on rope nets (Rimböck, 2004). Furthermore, advanced tools for modelling woody material recruitment storage and dynamics for small streams and their watersheds have been developed (Lancaster et al., 2001).

This work addresses the following questions from a hazard assessment perspective: 1) For which mountain torrents do woody material recruitment and transport phenomena have be considered in hazard mapping? 2) Which mountain torrents are supposed to react in a sensitive way in terms of increasing hazard impacts if woody material transport occurs? 3) Which additional system loading and system response scenarios should be assumed, bearing in mind possible effects of woody material transport? 4) Can protection forest management policies be rationalized from a woody material transport hazard related perspective?

Based on these questions, the main objective of this study is to develop a procedure for generating hazard index maps (compare also Petraschek and Kienholz, 2003), in which the torrent catchments are classified according to their propensity to entrain and deliver woody material. Hazard index maps for debris flow and sediment transport and deposition processes already exist for the torrent catchments of the Autonomous Province of Bolzano/Bozen (Heinimann et al., 1998). These maps along with the newly created maps will constitute a reference on a hazard index level for the detection of the relevant hazard processes within each hazard assessment unit. In a successive analysis step the experts determine the hazard zones with more sophisticated procedures and can tailor the output maps to the requested level of detail.

\section{Method}

The proposed empirical method for the assessment of the hazard potential resulting from woody material recruitment and transport rests on the following outlined two step approach. In a first step the woody material recruitment areas are identified, localized and classified based on their capacity to increase the hazard potential of transport processes in alpine torrents. Woody material recruitment areas are defined as both vegetated torrent bed as well as wood-covered areas on hill slopes in close proximity or with a high connectivity to the torrent. In a second step an indicator for woody debris recruitment and transport is calculated for each torrent catchment. The application of a GIS based procedure, in which both aforementioned steps have been implemented, allowed for the generation of comprehensive hazard index maps for all torrential catchments of the Autonomous Province of Bolzano/Bozen. The level of detail of the procedure is restricted to the level of detail defined for hazard index maps (Petraschek and Kienholz, 2003).

\subsection{A hazard process oriented view of woody material dynamics}

As outlined by Rickli and Bucher (2006), the volume of the transported woody material in a defined torrent reach is a product of: 1) the transport process in the considered reach (e.g. inflow and outflow of woody material), 2) the potentially recruitable woody material along the banks and the channel bed, if vegetated (e.g. vegetated bars), and 3) the recruitment processes taking place on hill slopes. Rickli and Bucher (2006) identify the following relevant recruitment processes:

1. Bank erosion: Through the shear stress exerted on the wetted perimeter of the cross-section of the channel erosion processes occur along the banks altering the static equilibrium of the trees that can topple or slide into the channel. Hazard increasing conditions of synchronism between debris flow or flood events and the above mentioned woody material recruitment process is quite probable.

2. Wind-throw: strong wind conditions can either destabilize the trees that consequently fall as a whole into the channel, or lead to the recruitment of the epigeous parts, if their stems break under the wind loading. May and Gresswell (2003) point out that falling trees with a horizontal distance to the channel that exceeds their height can exert a destabilizing action on other trees (e.g. knock-on effect).

3. Snow loading: the pressure exerted by the snow, in particular wet snow in spring and autumn, can cause stability problems to broad-leaved trees increasing bending moments and shear forces. Through the concurring 
cleaving action of ice, crowns of trees are susceptible to break off.

4. Landslides and other slope processes convey standing and lying woody material within the process perimeter towards the channel. Woody material temporarily stored in steep gullies on hill slope areas can also be conveyed toward the channel in connection with mass movements.

5. Avalanches are likely to incorporate and convey large volumes of woody material within the process perimeter.

As a general rule, in the case of debris flows, a large part of the available woody material within the discharge crosssection is likely to be entrained and transported. In the case of flood processes above a threshold discharge value, entrainment of woody material starts due to the fact that the destabilizing forces (drag and buoyancy forces) exceed the resisting forces (friction and the gravity component normal to the channel bed). It has been evidenced by flume experiments (Braudrick and Grant, 2000; Bezzola et al., 2003) that in larger mountainous streams, characterized by channel widths greater than the wood element length, entrainment depends on the orientation of the wood element in relation to a series of parameters. These parameters are the flow direction, the roughness of the wood element, the roughness of the stream bed, the density of the wood and the ratio between wood element diameter and flow depth. In smaller streams transport phenomena are characterized by a certain intermittency involving pivoting and jamming of the wood elements.

In the following sections, a classification scheme of the woody material recruitment areas is proposed (Sect. 2.2) and subsequently these areas are identified and spatially delimitated (Sect. 2.3).

\subsection{Classification of the woody material recruitment areas}

Referring to the description of the dynamics of woody material briefly outlined in the previous section, the recruitment areas are classified according to the following criteria: 1) wood stand productivity, 2) activity/intensity of the recruitment processes, and 3) activity/intensity of torrential processes:

1. SIZ-areas ("stream influence zone"): The extent of these areas is determined by the wetted perimeter corresponding to the peak discharge of the considered extreme event of the debris flow or flood with intense bedload transport, depending on the dominant process (compare Sect. 2.3 for details). Hazard index maps for debris flows and floods with intense sediment transport for the torrent catchments of the Autonomous Province of Bolzano/Bozen have been produced (Staffler et al., 2008). The SIZ-areas include either the areas exposed to debris flows, overbank sedimentation or the channel beds. Tree and shrub vegetation of the banks and the torrent bed which is directly exposed to the hydrodynamic forces is easily entrained. Vertical and lateral erosion can significantly reinforce the entrainment process (compare Fig. 1).

2. AWB-areas ("active wood buffer"): These active recruitment areas border the SIZ-areas. Toppling trees can directly reach the stream and considerably influence geomorphologic processes (compare Fig. 2). Autochthonous jams are made of woody material that has not been entrained from the point where it first entered the channel, although it may have rotated or the channel may have moved (Abbe and Montgomery, 1996). Up to a certain intensity of the flood process, the formation of these jams has a stabilizing effect on the stream bed, but for higher intensities mobilization of the woody material starts to occur.

3. RWB-Areas ("recharging wood buffer"): This forested band is directly connected to the outside of the AWB. Toppling trees cannot reach the stream bed directly, but as evidence from documented events underpins, they can destabilize other trees from the AWB (compare Fig. 2) or in extremely steep and cliffy areas they can slide into the stream bed. The parameters determining the width of the AWB and the RWB are the fundamental parameters of the forest stands and geomorphologic parameters. For most areas in the Autonomous Province of Bolzano/Bozen a georeferenced map of the potential forest types is available (Klosterhuber et al., 2007). The parameter which correlates well with the wood stand productivity is the dominant height or top height, which is relatively independent from thinning measures. The dominant stand height $h_{r}$ is the predicted height of the quadratic mean of diameters of the $20 \%$ largest trees per stand (Kramer and Akça, 1995). The geomorphologic influence is represented by the inclination of the hill slope.

4. PRP ("preferential recruitment paths"): These are mainly steep stream channels in forested areas reaching the main channel. In these cases, transportation of woody material is possible even if the width of the AWB and the RWB is exceeded. The identification of these channels and areas is based on the hazard index map for debris flows and overbank sedimentation as well as on the event documentation of the Department of Hydraulic Engineering (Autonome Provinz Bozen Südtirol - Abteilung Wasserschutzbauten, 2008).

d) PCA ("preferential contributing areas"): These are areas of potential shallow landslides in forested areas close to the stream channel (compare Fig. 3). Using models such as SHALSTAB (Dietrich and Montgomery, 1998) or SINMAP (Pack et al., 1998) to identify these areas enables the 


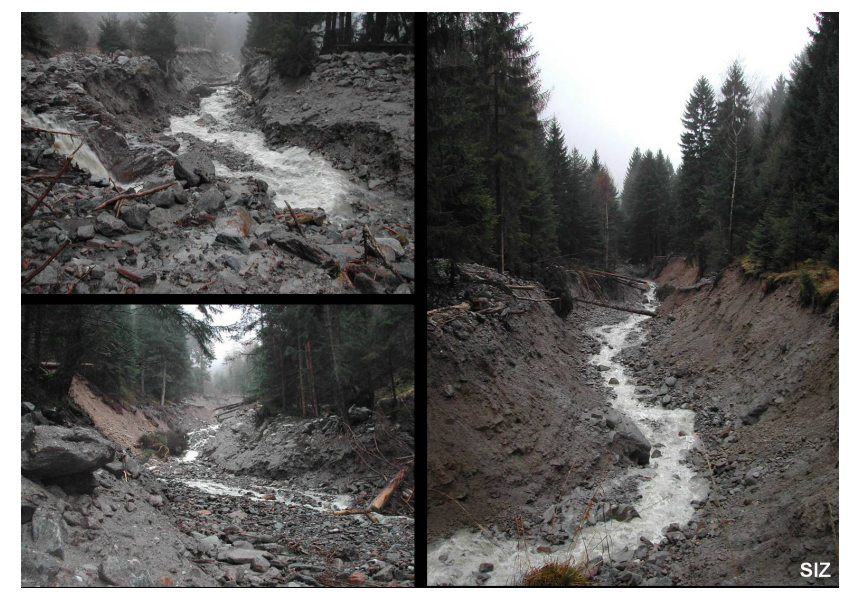

Fig. 1. SIZ-zone: torrential processes with influence on entrainment and transport of woody material.

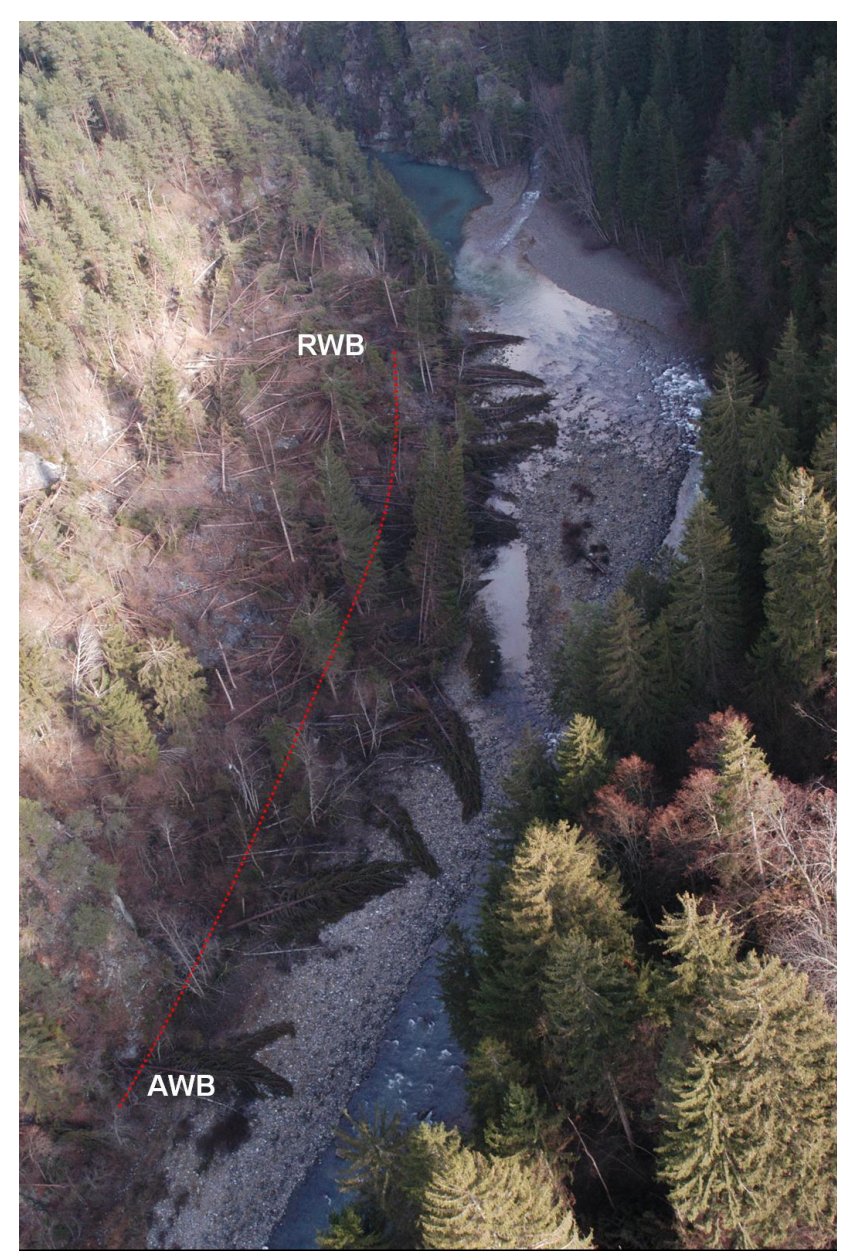

Fig. 2. AWB-areas and RWB-areas: recruitment mechanisms on hillslopes.

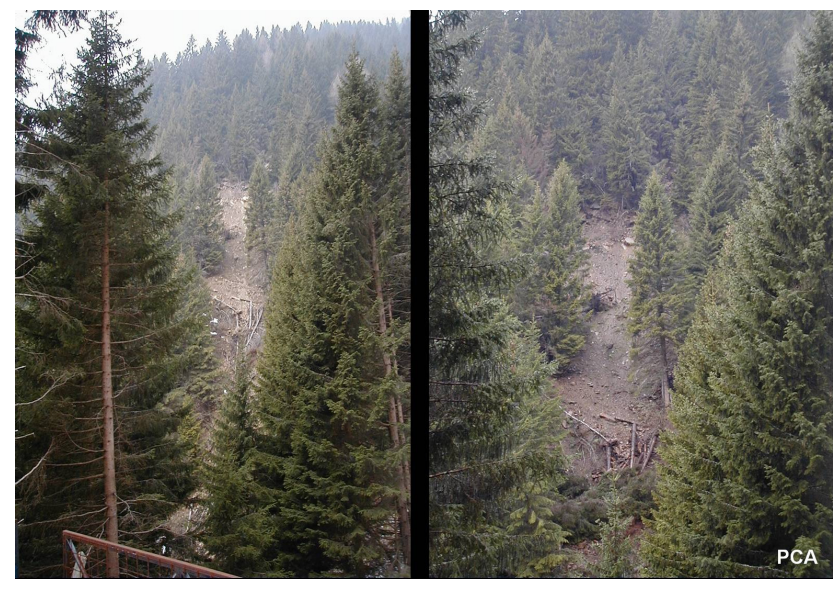

Fig. 3. PCA-areas: particularly active recruitment areas on hillslopes.

assessment of known and previously unknown areas of shallow landslides.

Regarding the fact that PRP and PCA provide particularly significant woody material recruitment, they are called "particularly active recruitment areas" (PARA). Figure 4 illustrates schematically the classification scheme adopted for the recruitment areas and the relevant processes involved. Figure 5 shows schematically the spatial distribution of the different recruitment areas.

\subsection{Identification and spatial delimitation of the woody material recruitment areas}

In this step, the woody debris recruitment areas were identified on the basis of existing datasets concerning forest cover, topography, hydrography and hydrology. The areas bordering the channel were selected. Furthermore, forested areas were identified which are prone to debris flows and shallow landslides and the connectivity of these areas to the stream bed was analysed. In a second step, the driftwood transport capacity of the stream is quantified using an indicator based on distinct topographic parameters. The combination of the delimited types of recruitment areas lead to the calculation of an index for the recruitment and transport capacity for woody debris of the torrent catchments.

The procedure used the following existing datasets:

- The digital terrain model of the Autonomous Province of Bolzano/Bozen with a resolution of $20 \mathrm{~m}$.

- The hazard index map for debris flow and overbank sedimentation processes (Staffler et al. 2008). This dataset identifies and localizes the potential debris flow hazard zones. The map was elaborated on the basis of the digital elevation model, the vegetation map and the geological map following the procedure of Zimmermann et al. (1992 and 1997) and Heinimann et al. (1998). 
- The map of the classified land use of the Autonomous Province of Bolzano/Bozen (Autonome Provinz Bozen - Südtirol 2004). The forest cover was extracted from this map.

- The map of the modelled forest vegetation typologies (Klosterhuber et al., 2007). From this map, the potential tree heights were delineated.

- The map of the alpine torrent catchments. This dataset delimitates the alpine torrent catchments with debris flow and overbank sedimentation processes.

In the first step, the torrent channels were derived from the digital terrain model. According to the formulas (1), (2) and (3), the areas of the active wood buffer (AWB) and the recharging wood buffer (RWB) along the torrent channels were determined.

(a) Calculation of the width of the active wood buffer (AWB) and the recharging wood buffer areas (RWB)

The probability of recruitment from a riparian forest on a plain surface is a function of a tree's height and distance from the stream, measured perpendicularly from the position of the tree to the nearest channel boundary (Robison and Beschta, 1990). The probability space for a tree falling is a disk centred on the tree with radius equal to the tree's height. Van Sickle and Gregory (1990) quantified the probability of a tree entering the stream as follows:

$P_{S}=\frac{\cos ^{-1}\left(\frac{z}{h}\right)}{180}$

$P_{s}$ - probability of entry; $z$ - perpendicular distance to the nearest channel boundary (in our model the border of the SIZ-area); $h$ - effective tree heigth.

The width of the AWB-areas on a plain surface $w_{\mathrm{AWB}}$ is obtained setting the probability of entry in Eq. (1) equal to zero and setting $h$ equal to the top height of the forest type. Therefore, for hill slopes with slope inclination less than $40 \%$, the width of the AWB-areas, is estimated as follows:

$w_{\mathrm{AWB}}=h_{r}$

$w_{\mathrm{AWB}}$ - width of the AWB; $h_{r}$ - top tree height.

As pointed out by Sobota et al. (2006), individual trees exhibit a stronger tendency to fall towards the channel on steep hillslopes $(>40 \%)$ than on moderately sloped landforms $(<40 \%)$. Integration of field data into an established recruitment model indicated that 1.5 to 2.4 times more large wood (by number of tree boles) would be recruited to stream reaches with steep hillslopes than to reaches with moderate side slopes or flat banks, if riparian forest conditions are assumed to be constant. They conclude that stream valley topography should be considered in models that use tree fall directions in predictions of large wood recruitment to streams.
For wood stands on hill slopes (slope $\geq 40 \%$ ), the width of the active wood buffer was determined as follows:

$w_{\mathrm{AWB}}=k \cdot h_{r}$

$k$ - coefficient $(1.5 \leq \mathrm{c} \leq 2.4)$ for steep slopes (Sobota et al., 2006). On a hazard index level an average value of 1.95 has been chosen for the coefficient $k$.

Accounting for particular impact factors, such as wind throw or high forest dieback, the value of coefficient $k$ in Eq. (3) should be increased, provided that experimental data is available.

As suggested by Harrington and DeBell (1996), in dense, spindly stands where the crowns support each other, trees can bend over and collapse entire sections of the stand (the domino effect).

After considering these impact factors, the additional buffer area (i.e. RWB) was identified. Due to falling trees within the RWB-area, destabilizing repercussions in the ABW-area can be expected. The width of the RWB-area was calculated analogously to the determination of the AWB-area as follows:

$w_{\mathrm{RWB}}=d \cdot h_{r}$

$d$-coefficient for the knock-on effect.

On a hazard index level a value of 1 has been chosen for the coefficient $d$. Accounting for particular impact factors, such as wind throw or high forest dieback, the value of coefficient $d$ in Eq. (4) should be increased, provided that experimental data is available.

A higher accuracy level in the determination of extents of the AWB and RWB areas, as required for the production of hazard maps rather than on a hazard index level, can be achieved deserving particular attention to connectivity (Borselli et al., 2008), that could influence the recruitment to stream. Using a high resolution digital elevation model (e.g. cell size of $2.5 \mathrm{~m} \cdot 2.5 \mathrm{~m}$ ), all possible falling directions ( $\max$ 8 directions) are determined for a tree (height equal to the top height), standing in the centre of the corresponding cell, that potentially permits recruitment (distance from SIZ-outward boundaries less than $w_{\mathrm{AWB}}$ ). Connectivity is checked along each possible direction. The following connectivity criteria can be applied:

1) Connectivity is given along a possible tree fall direction, if the elevation profile along the tree fall direction does not exceed the linear elevation profile given by the straight line that connects the cell centre of the tree location with the cell centre of the cell identifying the SIZboundary.

2) If the elevation profile along the tree fall direction exceeds the linear elevation profile given by the straight line that connects the cell centre of the tree location with the cell centre of the SIZ-boundary cell the situation is different. It has to be checked whether or not the tree 


\section{WOODY DEBRIS RECRUITMENT - general scheme case: HILLSLOPE}

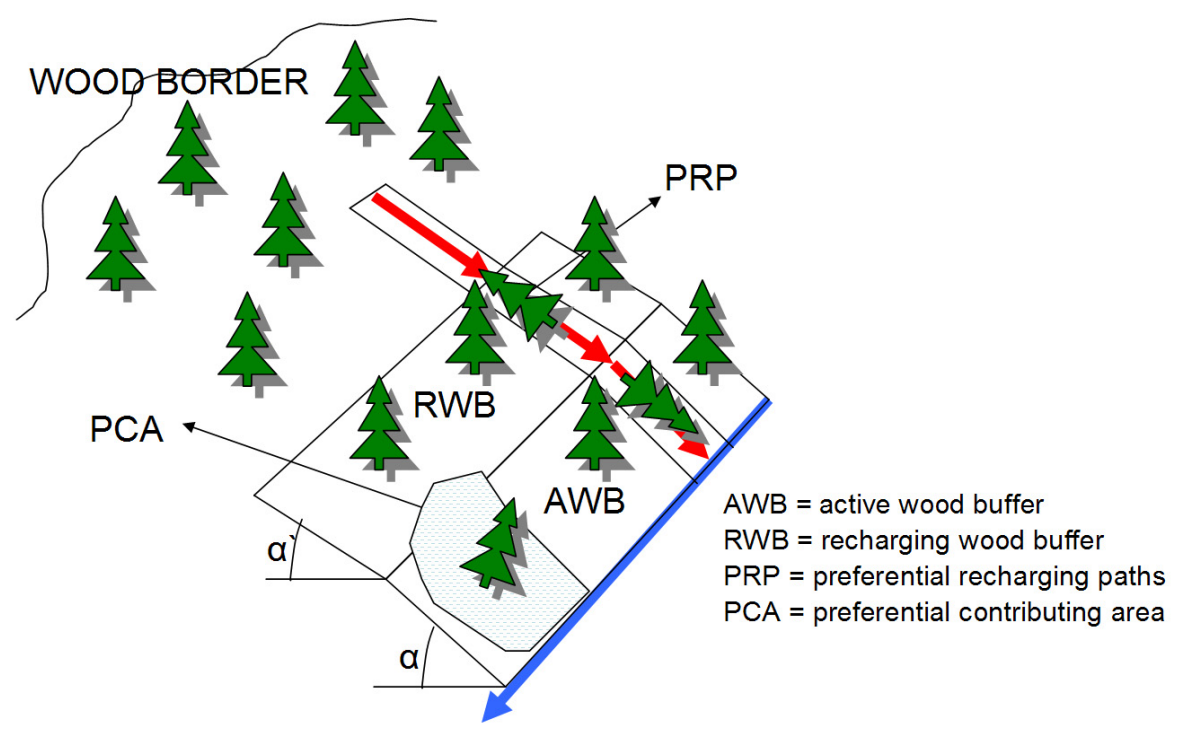

Fig. 4. Schematic illustration of the types of woody debris recruitment areas.
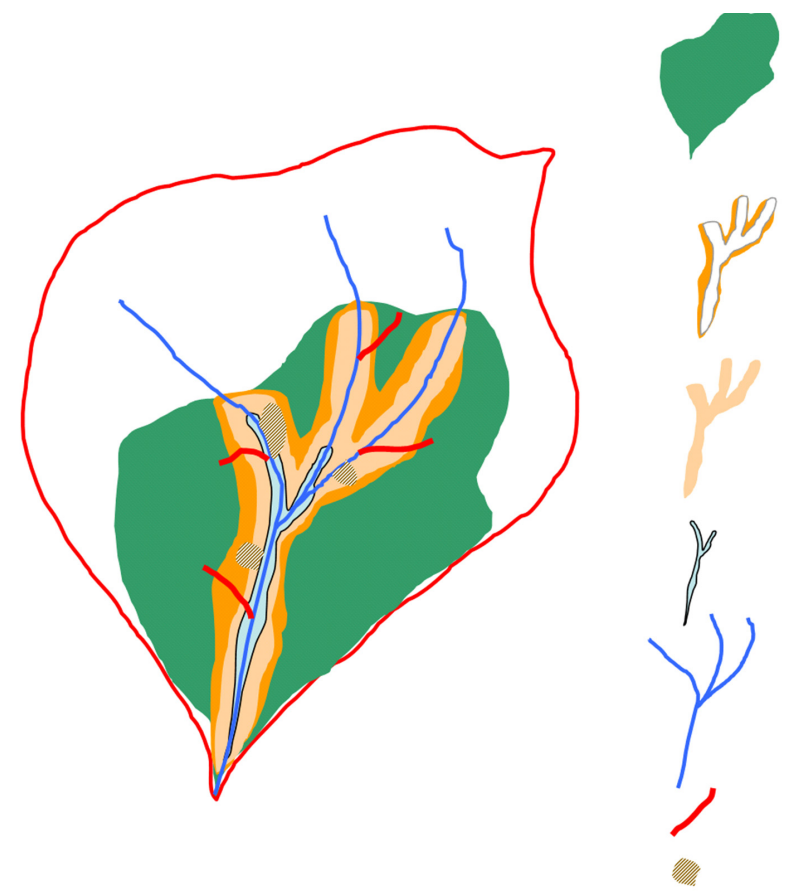

Wooden area in the watershed: this area is subdivided in more wood types with certain characteristics: rth (mean tree height), wood density, different spices and so on

$\mathrm{RWB}=$ recharging wood buffer

AWB = active wood buffer

$S \mid Z=$ stream influence $z o n e$

$\mathrm{BL}=$ blue line

PRP = preferential recharging paths

PCA $=$ preferential contributing areas

Fig. 5. Schematic illustration of the spatial delimitation of the different types of woody debris recruitment areas.

can tilt over the obstacles, which is defined here as the vertical props given by the cell centres with exceeding elevations with respect to the corresponding elevations of the straight connecting line.
In this way the tree fall directions which don't meet the connectivity criteria can be excluded.

It should be noted that the level of accuracy for hazard indexes uses a cell size of $20 \mathrm{~m} \cdot 20 \mathrm{~m}$ for computations. Moreover, if we consider that the top tree heights are not larger 
than $40 \mathrm{~m}$ (Klosterhuber et al., 2007), only the case of one intermediary cell between the tree location cell and the SIZ boundary cell is possible. In this case a simplified connectivity check is proposed. Connectivity is assumed to be given along a certain tree fall direction if the elevation of the intermediary cell does not exceeds the elevation of the tree location cell.

(b) Identification of the preferential recruitment paths (PRP)

These areas were extracted from the hazard index maps for debris flows and overbank sedimentation processes. The preferential recruitment paths were identified and localized by geomorphic analyses of either the digital terrain model or the dataset of the superficial watercourses (after Zimmermann et al., 1992 and Heinimann et al., 1998). Steep and concave flowlines which are hydrologically connected with the SIZ areas were classified as PRP areas. Along these preferential recruitment paths woody material can be transported to the SIZ-areas from unstable forested areas despite that these recruitment areas are not topologically connected to the SIZ-areas themselves. If it is required, this information can be integrated with pre-existing maps from the event documentation database.

(c) Identification of the preferential contributing areas (PCA)

In a first step, the potentially unstable areas were identified and localized using the GIS-based approach for calculating the slope stability (SHALSTAB, Dietrich and Montgomery, 1998). The unstable areas resulting from this procedure were intersected with the forest cover. In a further step, the active landslides were extracted from the landslide inventory of the Autonomous Province of Bolzano/Bozen (IFFI). Both the evident and the potentially unstable forested areas bordering or being hydrologically connected with SIZ areas through the PRP areas were considered as PCA.

(d) Identification of the particularly active recruitment areas (PARA)

These areas result from the union of the PRP and the PCA.

(e) Identification of the torrent influence zones (SIZ)

In this study, the SIZ-zone was determined based on the hazard index maps for debris flow and for overbank sedimentation processes, including their transit and deposition areas (Staffler et al., 2008).

The analysis was made on a cell-by-cell basis for the whole territory of the Autonomous Province of Bolzano/Bozen - South Tyrol. The vector datasets were converted into raster datasets with the same resolution of the digital elevation model. Outputs of this step were the classified woody debris recruitment areas in the pre-defined torrent catchments.

\subsection{A woody material recruitment indicator}

After the identification of the potential woody debris recruitment areas, the indicator for the woody debris recruitment is calculated for each pixel and cumulated for each torrent catchment.

For every pixel in the stream channel the contributing woody debris recruitment areas are summarized using the following indicator:

$$
\begin{aligned}
\mathrm{RA}_{h s, i}= & a \cdot\left(\mathrm{AWB}_{l e f t, i}+\mathrm{AWB}_{r i g h t, i}\right) \\
& +b \cdot\left(\mathrm{RWB}_{l e f t, i}+\mathrm{RWB}_{r i g h t, i}\right) \\
& +c \cdot\left(\mathrm{PARA}_{l e f t, i}+\mathrm{PARA}_{r i g h t, i}\right)
\end{aligned}
$$

$\mathrm{RA}_{h s, i}$ - recruitment areas on hill slopes connected to the $i_{t h}$ stretch of the stream.

The weighting coefficients $a, b$ and $c$ in Eq. (5) are calibration parameters which should be adapted according to the regional conditions. By means of an extensive analysis of the debris flow and overbank sedimentation events which occurred in the Autonomous Province of Bolzano/Bozen since 1998, the following procedure was used for the estimation of the parameter $c$. The process was based on visual inspection and image interpretation of adequately geo-referenced images. The active PARA-areas during the considered extreme events were localized and geo-referenced. On the basis of the high quality orthophoto-images from the year 2006, the ratio $r_{V 1}$ was estimated for wood volume $V_{\text {PARA }}^{t}$ within the PARA-areas to the wood stand volume outside $V_{\text {WOOD }}^{t}$ the PARA-areas (in the majority of the cases this involved the AWB- or RWB-areas). Additionally, pictures from the event documentation corresponding to the areas in the orthophotos were used to estimate the ratio $r_{R 1}$ of wood volume $V_{\text {PARA }}^{t+1}$ still available after the event at time $t+1$ to the wood volume $V_{\text {PARA }}^{t}$ present before the event at time $t$. The conditions of the wood in the PARA-areas before the event at time $t$ were assumed to be comparable to those of the year 2006. The fact that $V_{\text {WOOD }}^{t}$ can differ from the potential wood stand volume $V_{\mathrm{POT}}^{t}$ analyzed by Klosterhuber et al. (2007), the ratio $r_{P 1}$ of $V_{\text {WOOD }}^{t}$ to $V_{\text {POT }}^{t}$ should be recognized; however, assuming the requirements of the hazard index level $r_{P 1}=1$, the coefficient $c$ can be expressed in terms of $r_{V 1}$ and $r_{R 1}$ as follows:

$c=r_{V 1}\left(1-r_{R 1}\right)$

In practice, a set of representative PARA-area were analyzed in different catchments and the above defined ratios were estimated. An area-weighted average value $c_{\mu}=0.48$ is used in the calculations.

A qualitative comparison between the recruitment processes occurring in PARA-areas and in AWB-areas of similar extent gave rise to the assumption that although recruitment from AWB-areas is an order of magnitude lower than recruitment from PARA-areas during extreme events, the recruitment from AWB-areas in the long term is a more continuous process. Taking into account the effects of wood degra- 


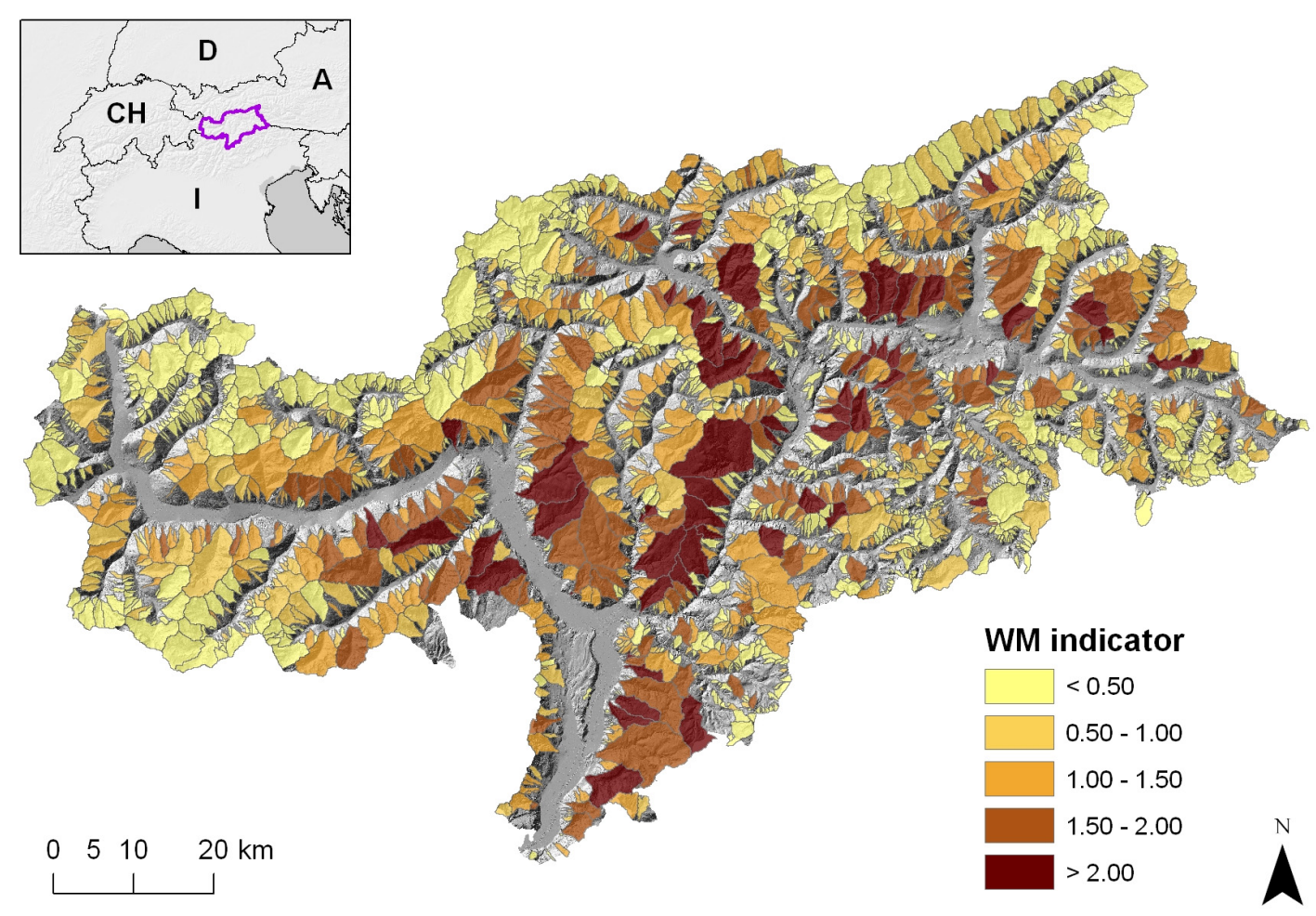

Fig. 6. Classification of the torrent catchments by the woody debris recruitment and transport indicator WM. Legend classification in equal intervals.

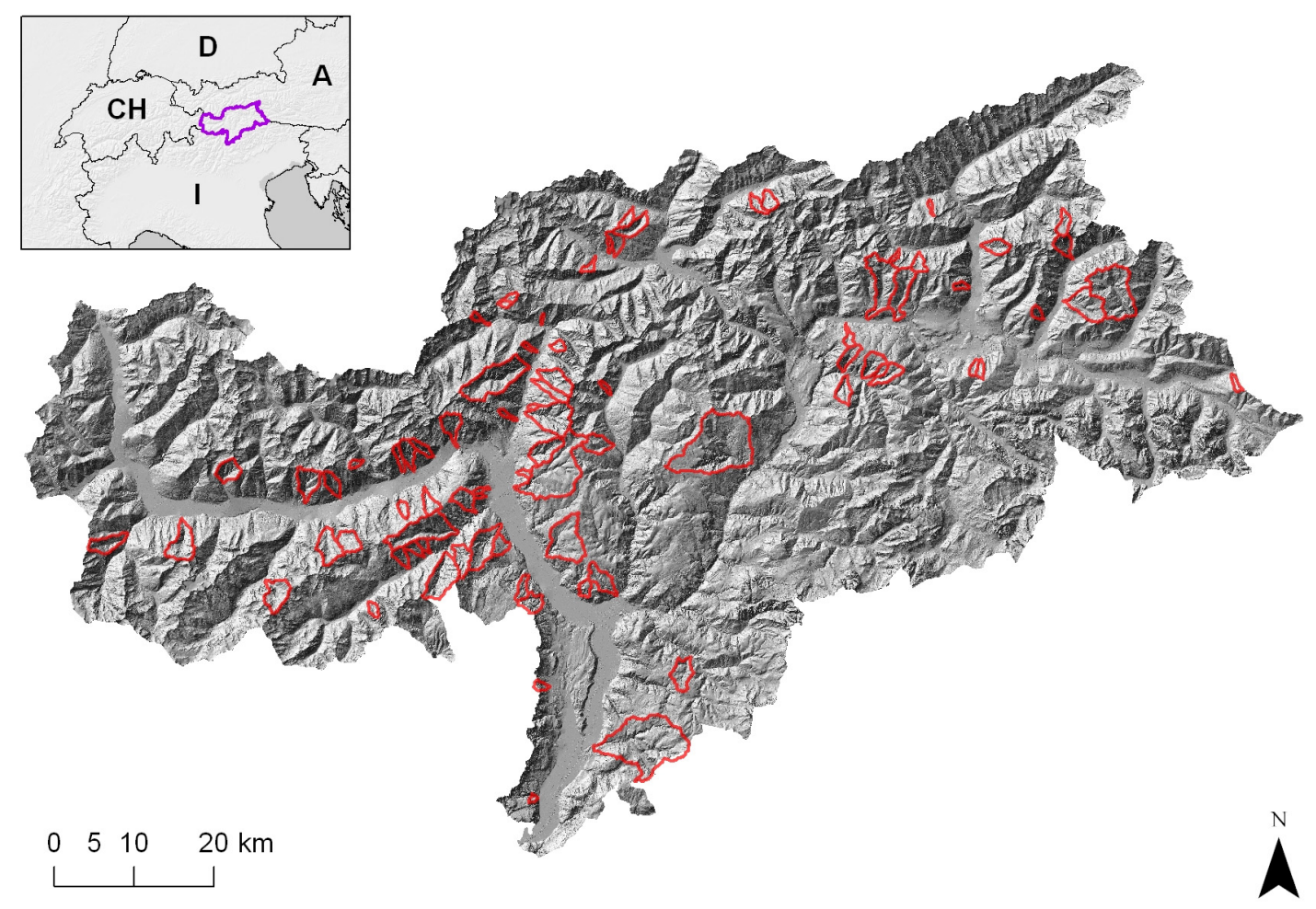

Fig. 7. Torrent catchments with observed woody material recruitment and transport during documented debris flow and overbank sedimentation processes. 
dation in the long term, the weighting factor $a$ for the recruitment contribution from the AWB-areas is chosen to be $a=0.5 \cdot c$. The indirect influence on the recruitment process of the RWB-areas justified the assumption $a>b$ and subsequently a value of $b=0.2 \cdot a$ was chosen.

Within the SIZ-areas more concurring processes take place: recruitment within the SIZ-area of tree and shrub vegetation of the banks and the torrent bed directly exposed to the hydrodynamic forces, entrainment, transport and deposition of the woody material. The recruitment process is modelled analogously to the above described processes occurring on the slopes as follows:

$\mathrm{RA}_{\text {instream, } \mathrm{i}}=d \cdot\left(\mathrm{SIZ}_{i}\right)$

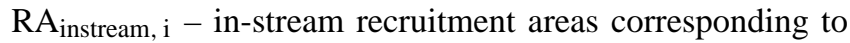
the $i_{t h}$ stretch of the stream.

The following ratios have been defined: a) ratio $r_{V 2}$ of wood volume $V_{\text {TIZ }}^{t}$ within the SIZ-areas to the wood stand volume outside $V_{\text {WOOD }}^{t}$ and b) ratio $r_{R 2}$ of wood volume $V_{\text {TIZ }}^{t+1}$ still available after the event at time $t+1$ to the wood volume $V_{\mathrm{TIZ}}^{t}$ present before the event at time $t$. The coefficient $d$ was qualitatively assessed as follows:

$d=r_{V 2}\left(1-r_{R 2}\right)$

Due to the strong influence of the process type on in-stream recruitment, different coefficients for debris flows $\left(d_{1}\right)$ and intense bedload transport processes with overbank sedimentation $\left(d_{2}\right)$ have to be defined. A set of representative events were analyzed in different catchments and the above defined ratios were estimated. The area-weighted values of $d_{1, \mu}=0.46$ and $d_{2, \mu}=0.27$ were used in the calculations.

Subsequently the contributing in-stream recruitment areas were cumulated for each pixel in the stream channel as follows:

$\mathrm{RA}_{\text {tot }, \mathrm{i}}=\mathrm{RA}_{h s, i}+\mathrm{RA}_{\text {instream, } \mathrm{i}}$

$\mathrm{RA}_{\text {tot, }}$ i total recruitment areas connected to the $i_{\text {th }}$ stretch of the stream.

\subsection{An indicator for woody material entrainment and transport}

Streams with a low longitudinal slope require a certain flow depth ( $\left.h \geq 2 d_{\mathrm{BHD}}\right)$ and channel width ( $\left.b \geq L_{\text {woody material }}\right)$ as well as an adequate radius of curvature in order to support woody material transport over major distances (Braudrick et al., 1997). In torrents with intense bedload transport the entrainment and transport process are facilitated by the coupled action of hydrodynamics and mobile bed dynamics. In torrents with debris flow activity the driftwood is easily entrained and incorporated in the mixture of solid material and water. In this process, the driftwood can be partially broken up and, in the absence of obstacles, it can be transported to the depositional area. The following parameters are relevant to describe entrainment and transport of woody material on a hazard index level.

$Q$ - peak total discharge (liquid and solid) at the closure section of the catchment for a 100-years return period event.

The liquid discharge $Q$ for a 100-years return period event is given on a regionalized basis by the following expressions (Ferrari, 1996):

$Q=10.31 \cdot A^{0.593}$ in the Western Adige/Etsch basin

$Q=12.69 \cdot A^{0.606}$ in the Eastern Adige/Etsch basin

$A$ - catchment area in $\left[\mathrm{km}^{2}\right]$.

$Q_{\text {tot }}$ is derived specifically for either 1) floods with intense bedload transport and overbank sedimentation or 2) debris flows. For case 1), the solid discharge can be expressed according to Smart and Jaeggi's equation (1983):

$q_{s}=2.5 q J^{0.6}\left(J-\frac{d_{m}}{12.1 h_{m}}\right)$

$q_{s}$ - solid discharge per unit width of the channel $\left[\mathrm{m}^{3} /(\mathrm{m} \cdot \mathrm{s})\right]$, $q$ - liquid discharge per unit width of the channel $\left[\mathrm{m}^{3} /(\mathrm{m} \cdot \mathrm{s})\right]$, $J$ - Channel slope $[\mathrm{m} / \mathrm{m}], d_{m}$ - characteristic grain-size diameter [m], $h_{m}$ - average flow depth [m].

Assuming that $d_{m} \ll 12.1 h_{m}$ and that $b$ is the channel width, Eq. (11) can be simplified to:

$Q_{s}=2.5 Q J^{1.6}$

$Q_{s}=q_{s} \cdot b-$ solid discharge $\left[\mathrm{m}^{3} / \mathrm{s}\right], Q=q \cdot b-$ liquid discharge $\left[\mathrm{m}^{3} / \mathrm{s}\right]$.

Subsequently, in the bedload transport case, the total discharge $Q_{\text {tot }}$ can be expressed by:

$Q_{\text {tot, bedload }}=Q+2.5 Q J^{1.6}=\left(1+2.5 J^{1.6}\right) Q$

For case 2), the debris flow peak discharge is estimated through Takahashi's volumetric criterion $(1978,1980,1991)$ :

$Q_{\text {tot }, \mathrm{df}}=Q \frac{C^{*}}{C^{*}-C_{d f}}$

$C_{d f}-$ concentration of the granular mixture, $C^{*}=0.65-$ maximum possible concentration, $C_{d f}-$ can be expressed as follows:

$C_{d f}=\frac{\tan \alpha}{\Delta(\tan \phi-\tan \alpha)}$

$\Delta$ - relative density of the submerged material, here assumed to be equal to $1.65, \alpha$ slope angle of the channel, $\phi$ friction angle of the granular material, here assumed to be equal to $32^{\circ}$.

The following two additional parameters need to be defined:

- The average downstream longitudinal slope from the $i_{t h}$ section to the basin outlet section, $J_{d s, i}$. 
The ratio $l_{Q, i}$ assigns a certain portion of the maximum discharge to every section of the channel depending on the location in the catchment, and is calculated as follows:

$l_{Q, i}=\frac{Q_{i}}{Q}$

$Q_{i}-100$ years return period liquid discharge at the $i_{t h}$ section, $Q-100$ years return period liquid discharge at the basin outlet section.

For the estimation of the woody material entrainment and transport potential the following indicator is proposed:

Indicator WM for the bedload transport case:

$\mathrm{WM}=Q_{\text {tot, bedload }} \cdot \frac{1}{A_{\text {tot }}} \cdot \sum_{i=1}^{k}\left(l_{Q, i} \cdot \mathrm{RA}_{\text {tot, } \mathrm{i}}\right)$

Indicator WM for the debris flow case:

$\mathrm{WM}=Q_{\text {tot, df }} \cdot \frac{1}{A_{\text {tot }}} \cdot \sum_{i=1}^{k}\left(l_{Q, i} \cdot \mathrm{RA}_{\text {tot }, \mathrm{i}}\right)$

$k$ - number of control points, $i=1, \ldots, k, A_{\text {tot }}-$ catchment area, WM - hazard potential indicator for wood material delivery.

The expression $\frac{1}{A_{\mathrm{tot}}} \cdot \sum_{i=1}^{k}\left(l_{Q, i} \cdot \mathrm{RA}_{\mathrm{tot}, \mathrm{i}}\right)$ is an estimate of the relative availability of recruited woody material and is a synthetic indicator for the transport conditions along the channel. $Q_{\text {tot, bedload }}$ or $Q_{\text {tot, df }}$ estimate the relative propensity for entrainment and delivery of woody material under given transport conditions.

The WM indicator was calculated for each raster cell in the specified catchments. The value of the indicator at the basin outlet section of each torrent catchment was assigned to the particular catchment in the dataset.

\section{Results}

This procedure both delimited and classified woody material recruitment areas and computed recruitment and transport indicators for the pre-defined torrent catchments. The computed recruitment areas showed a high spatial variability within many of the catchments. Verifications in the field on control samples showed a significant correspondence of the modelled woody material recruitment areas with the mapped recruitment areas.

The computed indicator WM showed a high spatial variability (Fig. 6). For torrent catchments with a low percentage of forest cover, low values for the WM indicator resulted $\left(\mathrm{WM}<5 \mathrm{~m}^{3} / \mathrm{s}\right)$. For steep and abundantly forested torrent catchments involving frequent debris flow processes, high values for the $\mathrm{WM}$ indicator resulted $\left(\mathrm{WM}>15 \mathrm{~m}^{3} / \mathrm{s}\right)$. The relevance of the catchment area and therefore the relevance of the peak discharge is visible in the results of the procedure. In general, higher values of the WM indicator were calculated in larger catchments; however, Fig. 6 shows that the weight $l_{Q, i}$ has an influence on these results. Small and steep catchments as well as large catchments with high discharge were associated with high values for the WM indicator, whereas in torrent catchments with a relatively low activity of torrential processes (small process areas), low values for the WM indicator were computed. Figure 6 shows that torrent catchments with a relatively high proportion of recruitment areas close to the end section had higher values for the WM indicators compared to catchments with a high proportion of recruitment areas in the upper parts of the catchments.

\section{Discussion}

Verifications in the field on control samples showed a significant correspondence of the modelled woody debris recruitment areas with the mapped recruitment areas. The developed procedure was validated on the basis of the event documentation database of the Department of Hydraulic Engineering of the Autonomous Province of Bolzano/Bozen. Figure 7 shows the torrent catchments with observed woody material transport by torrential processes. In a further step, the computed results have been shown to the local mountain torrent control and hydraulic engineering experts. High values for the WM indicator were computed for those catchments which were also considered susceptible to woody material transport phenomena in the opinion of the local experts. The calculated WM indicator was verified qualitatively and semi-quantitatively as described below. Although no systematic event documentation procedure exists regarding specific details of woody material transport during torrential events, the necessary data was reconstructed from database photographs of events. Nearly 1800 images showing woody material transported by debris flow and flood processes were extracted from this database and further georeferenced and analysed. On the basis of these images, the observed volume of transported material was estimated; however, these estimations were used for validation purposes in only a semiquantitative way, since the analysed photographs show only a very small part of the torrent catchments. The validation procedure showed a reliable correspondence of the calculated woody debris recruitment and transport indicators with the analysed photographs. In general, catchments with high values of the WM indicator were found to be those catchments which, in reality, are documented as having events with significant transport and deposition of woody material (Figs. 5 and 6). In torrent catchments with values of the WM indicator $>2 \mathrm{~m}^{3} / \mathrm{s}$, a minimum volume of $6 \mathrm{~m}^{3}$ of woody material could be estimated from the photographs (range from 6 to $154 \mathrm{~m}^{3}$, mean $35 \mathrm{~m}^{3}, n=11$ ). In torrent catchments with values of the WM indicator between 1 and $2 \mathrm{~m}^{3} / \mathrm{s}$, a minimum volume of $3 \mathrm{~m}^{3}$ of woody material could be estimated from the photographs (range from 3 to $130 \mathrm{~m}^{3}$, mean $25 \mathrm{~m}^{3}$, 
$n=51)$. There was one exception in which a sizeable wood volume was observed $\left(\sim 3 \mathrm{~m}^{3}\right)$ despite a low calculated WM indicator $\left(0 \mathrm{~m}^{3} / \mathrm{s}\right)$. This was due to the fact that the catchment was delimitated at the upper end of the alluvial fan and the observed wood material was recruited in the area of the alluvial fan itself. Given that the outlined method delineates catchments by a lower boundary at the alluvial fan or debris flow cone, the recruitment of woody material downstream of these outlet points is overlooked. For such scenarios other approaches must be used (e.g. considering the hydrodynamic impacts on the wood stand).

A quantitative comparison between the computed values for the WM indicator and transported woody material volumes failed due to the following three reasons. Firstly, the photographs focused on deposited woody material in the areas where damages occurred and often neglected areas in the stream influence zones. Secondly, the frequency of torrential events in the considered catchments could not be estimated. Thus, the volume of debris in a given picture may not be an accurate indicator of volume if the frequency of events in the past decades is high (i.e. material has been transported downstream in previous events). Thirdly, the intensity/frequency relationship of the documented event is not known and therefore, the comparison of the documented events with the scenario of a return period of 100 years is difficult. Nevertheless, the comparison showed a noticeable spatial correlation between the WM indicator and observed transportation and deposition of woody material.

\section{Conclusions}

The questions stated in the introductory chapter were successfully answered. The procedure enables the identification of those torrent catchments susceptible to woody material recruitment and transport which must be considered in hazard mapping. The detection of hazards related to woody material transport is a fundamental prerequisite for a robust and reliable risk assessment procedure for hydrologic hazards. In catchments with high values of the woody material transport indicator (WM), a detailed analysis of torrential processes occurring at critical configurations (e.g. bridge locations) is highly recommended. The knowledge derived from the generated hazard index maps supports a hind- and foresighted conceptual planning process of functional and efficient protection systems. Due to the higher weight given to the recruitment areas close to the end section of a catchment, the procedure is able to identify those catchments for which forestry measures should be checked (e.g. thinning the wood stand within the relevant stream influence zone).

Detailed results on a catchment scale can be obtained using high resolution digital elevation and surface models, performing hydrological computations by means of distributed hydrological models and retrieving detailed forest cover datasets (e.g. tree heights, areas with different canopy densities) and improving the parameter estimates for woody material recruitment and transport by ad hoc field surveys.

Regarding the young research stage of woody material transport processes, the possibility for further development of the application is a central aspect. In the authors' opinion, further improvements of the procedure could be attained by: a) introducing a probabilistic approach and connectivity indicators for the assessment of recruitment and b) using the results of 2-D hydrodynamic computations for the description of the time-dependent entrainment and transport processes within the SIZ-areas.

Acknowledgements. The project was co-financed by the European Union within the Interreg IIIA Italy-Switzerland project "Entwicklung und Anwendung eines Systems zur überregionalen Erkennung und Bewertung hydrogeologischer Risiken". The authors are indebted to Lorenzo Marchi for the hints and suggestions provided during the reviewing process that contributed to substantially improve the manuscript, to Omar Formaggioni for preparing the photographic material for the validation procedure and to Emily Procter for linguistically improving the text.

Edited by: F. Guzzetti

Reviewed by: L. Marchi and another anonymous referee

\section{References}

Abbe, T. B. and Montgomery, D. R.: Large woody debris jams, channel hydraulics and habitat formation in large rivers, Regul. River., 12, 2001-221, 1996.

Abbe, T. B., Montgomery, D. R., and Petroff, C.: Design of stable in-channel wood debris structures for bank protection and habitat restoration: an example from the Cowlitz River, WA, in: Management of Landscapes Disturbed by Channel Incision: Stabilization, Rehabilitation, Restoration, edited by: Wang, S.S.Y., Langendoen, E. J., and Shields, F. D., University of Mississippi, Mississippi, 809-815, 1997.

Autonome Provinz Bozen - Südtirol: Forst- und Weidewirtschaftliche Realnutzungskarte, Bozen, 2004.

Autonome Provinz Bozen - Südtirol - Abteilung Wasserschutzbauten: IHR - Informationssystem zu Hydrogeologischen Risiken, Methodischer Endbericht, Bozen, 2008.

Berger, E., Grisotto, S., Hübl, J., Kienholz, H., Kollarits, S., Leber, D., Loipersberger, A., Marchi, L., Mazzorana, B., Moser, M., Nössing, T., Riedler, S., Scheidl, C., Schmid, F., Schnetzer, I., Siegel, H., and Volk, G.: DIS-ALP. Disaster information system of alpine regions, Final report, unpublished, 2007.

Bezzola, G. R. and Lange, D.: Umgang mit Schwemmholz im Wasserbau, Wasser Energie Luft, 95(11/12), 360-363, 2003

Bezzola, G. R., Sigg, H., and Lange, D.: Driftwood retention works in Switzerland, Internationales Symposium Interpraevent 2004 Riva del Garda, 3, 29-40, 2004.

Borselli, L., Cassi, P., and Torri, D.: Prolegomena to sediment and flow connectivity in the landscape: A GIS and field numerical assessment, CATENA 75 (Elsevier), 268-277, 2008.

Braudrick, C. A., Grant, G. E., Ishikawa, Y., and Ikeda, H.: Dynamics of wood transport in streams: a flume experiment, Earth Surface Proc. Land., 22, 669-683, 1997. 
Braudrick, C. A. and Grant G. E.: When do logs move in rivers?, Water Resour. Res., 36(2), 571-583, 2000.

Braudrick, C. A. and Grant, G. E.: Transport and deposition of large woody debris in streams: a flume experiment, Geomorphology, 41, 263-283, 2001.

Comiti, F., Andreoli, A., Lenzi, M. A., and Mao, L.: Spatial density and characteristics of woody debris in five mountainrivers of the Dolomites (Italian Alps), Geomorphology, 78, 44-63, 2006.

Curran, J. H. and Wohl, E. E.: Large woody debris and flow resistance in step-pool channels, Cascade Range, Washington, Geomorphology, 51, 141-157, 2003.

Degetto, M.: Dinamica del legname in alveo e modellazione del suo comportamento in presenza di briglie filtranti, M.S. thesis, University of Padova, 2000.

Diehl, T. H.: Potential Drift Accumulation at Bridges, US Department of Transportation, Federal Highway Administration Research and Development, Turner-Fairbank Highway Research Center, Virginia, Publication No. FHWA-RD-97-028. 1997.

Dietrich, W. E. and Montgomery, D. R.: SHALSTAB: a digital terrain model for mapping shallow landslide potential, NCASI (National Council of the Paper Industry for Air and Stream Improvement) Technical Report, February 1998, 29 pp., 1998.

Ferrari, R.: Censimento e sicurezza di piccoli invasi in provincia di bolzano - relazione esplicativa, report for the office 30.6 of the Autonomous Province of Bolzano/Bozen, unpublished, 1996.

Fuchs, S. and McAlpin, M. C.: The net benefit of public expenditures on avalanche defence structures in the municipality of Davos, Switzerland, Nat. Hazards Earth Syst. Sci., 5, 319-330, 2005,

http://www.nat-hazards-earth-syst-sci.net/5/319/2005/.

Gurnell, A. M., Piegay, H., Gregory, S. V., and Swanson, F. J.: Large wood and fluvial processes, Freshwater Biol., 47, 601$619,2002$.

Haga, H., Kumagai, T., Otsuki, K., and Ogawa, S.:

Transport and retention of coarse woody debris in mountain streams: An in situ field experiment of log transport and a field survey of coarse woody debris distribution, Water Resour. Res., 38(8), 1126, doi:10.1029/2001WR001123, 2002.

Harrington, C. A. and DeBell, D. S.: Above- and below-ground characteristics associated with wind toppling in a young Populus plantation, Trees, 11, 109-118, 1996.

Heinimann, H., Hollenstein, K., Kienholz, H., Krummenacher, B., and Mani, P.: Methoden zur Analyse und Bewertung von Naturgefahren. Umweltmaterialen Bundesamt für Umwelt, Wald und Landschaft, Bern, 249 pp., 1998.

Hildebrand, R. H., Cemly, A. D., Dolloff, C. A., and Harpster, K. L.: Effects of large woody debris placement on stream channel and benthic macroinvertebrate, Can. J. Fish. Aquat. Sci. 54, 931939, 1997.

Keim, R. F., Skaugset, A. E., and Bateman, D. S.: Physical aquatic habitat: II. Pools and cover affected by large woody debris in three western Oregon streams, North American Journal of Fisheries Management, 22, 151-164, 2002.

Klosterhuber, R., Plettenbacher, T., Hotter, M., Schober, T., Aschaber, R., Vacik, H., Pircher, G., Gruber, G., and Ruprecht, H.: Ökologisches Handbuch zur Waldtypisierung und Waldstratifizierung Südtirol, Teil A, Zwischenbericht im Auftrag der Autonomen Provinz Bozen, Abteilung 32, Forstwirtschaft, 2007.
Kramer, H. and Akça, A.: Leitfaden zur Waldmesslehre, J.D. Sauerländers Verlag, Frankfurt am Main, Germany, 1995 (in German).

Lancaster, S. T. and Shannon, K. H.: Modelling Sediment and Wood Storage and Dynamics in Small Mountainous Watersheds, Geomorphic Processes and Riverine Habitat Water Science and Application, 4, 85-102, 2001.

Lange, D. and Bezzola, G. R.: Schwemmholz, Probleme und Lösungsansätze, Mittelungen der Versuchsanstalt für Wasserbau, Hydrologie und Glaziologie (VAW), Zurich, 2006.

Lyn, D., Cooper, T., Condon, D., and Gan, L.: Factors in debris accumulation at bridge piers, Washington, US Department of Transportation, Federal Highway Administration Research and Development, Turner-Fairbank Highway Research Center, 2007.

May, C. L. and Gresswell, R. E.: Large wood recruitment and. redistribution in headwater streams in the southern Oregon. Coast Range, USA, Can. J. Forest Res., 33(6), 1352-1362, 2003.

Montgomery, D. R. and Piegay, H.: Wood in rivers: interactions with channel morphology and processes, Geomorphology, 51, $1-5,2003$.

Oberndorfer, S., Fuchs, S., Rickenmann, D., and Andrecs, P.: Vulnerabilitätsanalyse und monetäre Schadensbewertung von Wildbachereignissen in Österreich, BFW, Wien, 2007.

Pack, R.T., Tarboton, D.G., Goodwin, C.N.: The SINMAP approach to terrain stability mapping. Proceedings of the 8th Congress of the International Association of Engineering Geology, Vancouver, British Columbia, Canada, Vancouver, 21-25 September 1998.

Petraschek, A. and Kienholz, H.: Hazard assessment and mapping of mountain risks in Switzerland, in: Debris-flow hazard mitigation:mechanics, prediction and assessment, edited by: Rickenmann, D. und Chen, C. L. (Hrsg.), Millpress, Rotterdam, 2003.

Rickenmann, D.: Schwemmholz und Hochwasser, Wasser Energie Luft, 89, 115-119, 1997.

Rickli, C. and Bucher, H.-U.: Schutzwald und Schwemmholz in Wildbacheinzugsgebieten, FAN-Agenda 1/06, 17-20, 2006.

Rimböck, A.: Design of rope net barriers for woody debris entrapment, Introduction of a design concept, Proc. Int. Symp. Interpraevent 2004, Riva del Garda, Trento, Italy, 265-276, 2004.

Robison, E. G. and Beschta, R. L.: Characteristics of coarse woody debris for several coastal streams of southeast Alaska, USA, Can. J. Fish. Aquat. Sci., 47(9), 1684-1793, 1990.

Shields, F. D., Morin, N., and Kuhnle, R. A.: Effects of large woody debris structures on stream hydraulics, Proc. Wetlands Engineering and River Restoration Conference, ASCE, Reston, VA, 2001.

Smart, G. and Jaeggi, M.: Sediment transport on steep slopes, Mitteilungen der Versuchsanstalt für Wasserbau, Hydrologie und Glaziologie, Zürich, Nr. 64, 1983.

Sobota, D. J., Gregory, S. V., and Van Sickle, J.: Riparian tree fall directionality and modeling large wood recruitment to streams, Can. J. Forest Res., 36(3), 1243-1254, 2006.

Staffler, H., Pollinger, R., Zischg, A., and Mani, P.: Spatial variability and potential impacts of climate change on flood and debris flow hazard zone mapping and implications for risk management, Nat. Hazards Earth Syst. Sci., 8, 539-558, 2008, http://www.nat-hazards-earth-syst-sci.net/8/539/2008/.

Takahashi, T.: Mechanical characteristics of Debris Flow, J. Hydr. Eng. Div.-ASCE, 104(8), 1153-1169, 1978. 
Takahashi, T.: Debris Flow on prismatic open channel, J. Hydr. Eng. Div.-ASCE, 106(3), 381-396, 1980.

Takahashi, T.: Debris flows, Rotterdam, Balkema, 1991.

Uchiogi, T., Shima, J., Tajima, H., and Ishikawa, Y.: Design methods for wood-debris entrapment, Proc. Int. Simp. Interpreaevent, Garmisch Partenkirchen, 5, 279-288, 1996.

Van Sickle, J. and Gregory, S. V.: Modeling inputs of large woody debris from falling trees, Can. J.1 Forest Res., 20, 1593-1601, 1990.
Zimmermann, M., Mani, P., and Gamma, P.: Murganggefahr und Klimaänderung - ein GIS-basierter Ansatz. vdf, Zurich, 161 pp., 1997.

Zimmermann, M. and Haeberli, W.: Climatic change and debris flow activity in high mountain areas: a case study in the Swiss Alps, Catena Supplement, 22, 59-72, 1992. 